\title{
GMR
}

\section{Effect of polychlorinated biphenyls on oxidation stress in the liver of juvenile GIFT, Oreochromis niloticus}

\author{
Y. Zheng ${ }^{1,2}$, L.P. Qiu ${ }^{1}$, S.L. Meng' ${ }^{1}$ L.M. Fan ${ }^{1}$, C. Song ${ }^{1}$, D.D. Li ${ }^{1}$, \\ C. Zhang ${ }^{1}$ and J.Z. Chen ${ }^{1,2}$
}

${ }^{1}$ Freshwater Fisheries Research Center, Chinese Academy of Fishery Sciences, Scientific Observing and Experimental Station of Fishery Resources and Environment in the Lower Reaches of the Changjiang River, Wuxi, China ${ }^{2}$ Wuxi Fisheries College, Nanjing Agricultural University, Wuxi, China

Corresponding authors: Y. Zheng / J.Z. Chen

E-mail: zhengy@ffrc.cn / chenjz@ffrc.cn

Genet. Mol. Res. 15 (3): gmr.15038613

Received March 9, 2016

Accepted April 8, 2016

Published September 2, 2016

DOI http://dx.doi.org/10.4238/gmr.15038613

Copyright (C) 2016 The Authors. This is an open-access article distributed under the terms of the Creative Commons Attribution ShareAlike (CC BY-SA) 4.0 License.

\begin{abstract}
The present study clearly showed that chronic exposure to polychlorinated biphenyls (PCBs) at environmentally relevant concentrations can damage juvenile tilapia livers by modulating antioxidant enzyme activities and gene transcription, which affects toxic bioaccumulation and histological congestion. The results suggest that PCBs caused a decrease in the activity of some hepatic antioxidative and biotransformation enzymes (SOD, CAT, GST, T-GSH, and MDA) in tilapia at 7 days, as well as transcriptional changes ( $\operatorname{sod}$, cat, and $g s t$ ). Except for some antioxidant parameters (T-GSH, GSH/GSSG, T-AOC, and MDA), significant declines and increases occurred at 14 and 21 days, respectively. Most of the antioxidant enzymatic signatures and genotoxicity significantly increased at 14 and 21 days. This study
\end{abstract}

Genetics and Molecular Research 15 (3): gmr.15038613 
presented evidence that PCBs could result in hepatic toxicity through oxidative stress in the early growth stages of tilapia, and we speculated that oxidative stress plays an important role in embryonic developmental toxicity induced by PCBs.

Key words: Antioxidative enzyme; Genotoxicity; Oreochromis niloticus; Oxidation stress; Polychlorinated biphenyls

\section{INTRODUCTION}

The concentration of polychlorinated biphenyls (PCBs) in aquatic environments ranged from 1.7 to $29.8 \mathrm{ng} / \mathrm{L}$ in the Yangtze River, China (Ge et al., 2014). The total concentration of 24 PCBs in the water was $1.64 \mu \mathrm{g} / \mathrm{L}$ (Zhang et al., 2016). Long-term chronic exposure to PCBs has been associated with severe injury to the nervous, endocrine, reproductive, and immune systems in fish (Storelli et al., 2011). Oxidative stress is an important manifestation in fish, and the oxidative damage induced by chemicals in aquatic ecosystems can be assessed through the measurement of antioxidative enzyme activities in fish. PCBs are oxidative stress inducers that produce excess reactive oxygen species (ROS), which could result in hepatotoxicity (Wu et al., 2014a). The primary ROS was generated in the mitochondria. ROS detoxification could occur directly by antioxidant enzymes, such as the radical-scavenging enzymes superoxide dismutase (SOD; EC 1.15.1.1), catalase (CAT; EC 1.11.1.6), and glutathione peroxidase (GPx; EC 1.11.1.9), or indirectly by stabilizing the levels of glutathione (GSH) with the assistance of glutathione-S-transferase (GST, EC 2.5.1.18) and glutathione reductase (GR; EC 1.8.1.7).

Our previous study indicated that SOD, CAT, and GPx activities and their transcripts were significantly increased in pengze crucian carp (Carassius auratus) under heavy metal $\left(\mathrm{Cr}^{6+}\right)$ exposure (Li et al., 2013). Furthermore, mRNA expression of antioxidant genes (sod, cat, and gpx1) was strongly enhanced in the Chinese rare minnow (Gobiocypris rarus) by Aroclor 1254 (a highly chlorinated PCB mixture Wu et al., 2014a). In addition to frequently used oxidative stress markers (SOD, CAT, and GPx), the GSH-related antioxidant system attempted to protect the liver cells of Oreochromes niloticus from hepatotoxicity (Piner and Üner, 2013), and markers in this system include GST, GR activity, GSH content, and the GSH/GSSG ratio among others. Genetic Improvement of Farmed Tilapia (GIFT), O. niloticus, is sensitive to the stress of pollutants and is an ideal subject for toxicity experiments (Piner and Üner, 2013; Meng et al., 2014). The main purpose of the present study was to investigate the hepatic genotoxicity (transcriptional) and antioxidant enzymatic signature (post-transcriptional) in juvenile freshwater tilapia, O. niloticus, in response to 0.5 or $5 \mathrm{mg} / \mathrm{L}$ PCB exposure. The redox reaction is reversible and the GSH/GSSG ratio is associated with the redox state of fish under oxidative stress (Kim et al., 2005). The present study also examined the bioaccumulation of PCBs in tilapia liver and evaluated the redox state of tilapia at visual histological, biochemical, and molecular levels following exposure to PCBs.

\section{MATERIAL AND METHODS}

\section{Experimental design}

Fertilized eggs of GIFT were obtained from the Freshwater Fisheries Research Center of the Chinese Academy of Fishery Sciences, Yixing. Randomly selected 1-month-

Genetics and Molecular Research 15 (3): gmr.15038613 
old $O$. niloticus $(\mathrm{N}=720$, from 4.04 to $4.97 \mathrm{~g})$ were assigned to nine groups $(\mathrm{N}=80$ per aquarium). Fish were exposed to $0,0.5$, or $5 \mathrm{mg} / \mathrm{L}$ PCBs (Sigma-Aldrich, USA, containing PCB28, PCB52, PCB101, PCB118, PCB138, PCB153, and PCB180 at $10 \mathrm{mg} / \mathrm{L}$ per congener) for 21 days in triplicate. All exposure solutions were replaced every $48 \mathrm{~h}$. There were no statistically significant differences in body weight or length of exposure in the experiment. No fish mortality was observed. The actual total concentrations of PCBs to which groups were exposed in seawater were $0.45 \pm 0.05,4.62 \pm 0.38 \mathrm{mg} / \mathrm{L}$ for the 0.5 and $5.0 \mathrm{mg} / \mathrm{L}$ groups, respectively. We chose the high concentration based on strong resistance to challenge exposures in a previous study (Gabriel et al., 2015).

\section{Fish sampling and histological analysis}

In each group per sampling point (weekly), fish livers were sampled for gene expression $(\mathrm{N}=6)$, histological analysis $(\mathrm{N}=6)$, biochemical analysis $(\mathrm{N}=6)$, and a bioaccumulation $(\mathrm{N}=6)$ test. Samples for gene expression studies were homogenized using Trizol reagent (Invitrogen, USA), frozen in liquid nitrogen, and immediately stored at $-80^{\circ} \mathrm{C}$ until utilization. Sections of $7-\mu \mathrm{m}$ thick paraffin were cut with a rotary microtome and stained using the hematoxylin-eosin method after livers were fixed with a $4 \%$ formaldehyde fixative solution.

\section{Bioaccumulation of PCBs in juvenile O. niloticus liver}

Six fish livers were collected for PCB bioaccumulation detection. After the measurement of wet weight of juvenile fish, samples were extracted and the clean-up step and use of GC-MS equipment (Agilent 7890A-5975C) followed methods of Ottonello et al. (2014). DB-5 silica capillary tubing ( $30 \mathrm{~m} \times 0.32 \mathrm{~mm}$ x $0.25 \mu \mathrm{m})$ was used. Approximately 1 $\mathrm{g}$ liver was added with acetone/n-hexane $(1: 1, \mathrm{v} / \mathrm{v})$ for PCB extraction using the accelerated solvent extractor. A solid phase extraction silica cartridge was previously conditioned with 5 $\mathrm{mL}$-hexane, and the PCBs were eluted from the combined cartridges with $13 \mathrm{~mL}$-hexane. The extract was evaporated until dry using a rotary evaporator, and the residue was dissolved with $2 \times 500 \mu \mathrm{L}$ isooctane and evaporated with a gentle stream of nitrogen.

In brief, gas chromatographic temperature programs were as follows: initial temperature was $60^{\circ} \mathrm{C}$ held $2 \mathrm{~min}$; increased to $180^{\circ} \mathrm{C}$ at a rate of $30^{\circ} \mathrm{C} / \mathrm{min}$ and held $4 \mathrm{~min}$; increased to $200^{\circ} \mathrm{C}$ at a rate of $20^{\circ} \mathrm{C} / \mathrm{min}$ and held $8 \mathrm{~min}$; increased to $250^{\circ} \mathrm{C}$ at a rate of $20^{\circ} \mathrm{C} /$ min and held $5 \mathrm{~min}$, and then increased to $280^{\circ} \mathrm{C}$ at a rate of $30^{\circ} \mathrm{C} / \mathrm{min}$ and held $8 \mathrm{~min}$. The injector and detector temperatures were set at $300^{\circ} \mathrm{C}$. The ion source temperature was $240^{\circ} \mathrm{C}$. Quantitative analysis was performed in the selected ion-monitoring mode. The analytical limits of detection and quantitation were 0.32 and $0.51 \mu \mathrm{g} / \mathrm{kg}$, respectively. The concentration of PCBs is reported as microgram per kilogram of wet mass of the liver $(\mu \mathrm{g} / \mathrm{kg})$.

\section{Determination of oxidative stress}

For biochemical analyses, whole individual livers were homogenized on ice with cold $0.86 \%$ physiological salt water $(1: 9, \mathrm{w} / \mathrm{v})$, and then centrifuged at $2500 \mathrm{rpm}$ at $4^{\circ} \mathrm{C}$ for $10 \mathrm{~min}$. The supernatant was analyzed for activity of CAT, GPx, GR, GST, and SOD, and the content of malondialdehyde (MDA), T-GSH, and GSSG, and total protein and total antioxidant capacity (T-AOC) using commercial kits purchased from Nanjing Jiancheng Bioengineering

Genetics and Molecular Research 15 (3): gmr.15038613 
Institute, in triplicate (Nanjing, China). Tests were quantified spectrophotometrically with a PowerWave XS2 (BioTek Instruments Inc., Vermont, USA).

\section{RNA extraction, reverse transcription (RT) and qRT-PCR}

Total RNAs were extracted from juvenile $O$. niloticus livers using Trizol reagent (Invitrogen). The steps followed the methods of Zheng et al. (2013). The qRT-PCR was performed using the CFX96 Real-Time PCR System (Bio-Rad, USA) with SYBR (TaKaRa, Japan). $\beta$-actin was the most stable reference gene under exposure to PCBs in our study using the selection method described by Zheng et al. (2014) (data not shown). The qRT-PCR primers for $\beta$-actin, sod, cat, gr, gpxl, and gst are shown in Table S1. Changes in expression levels of these antioxidant genes after PCBs exposure were calculated by the $2^{-\Delta \Delta C t}$ method with the formula, $\mathrm{F}=2^{-\Delta \Delta \mathrm{Ct}}, \Delta \Delta \mathrm{Ct}=\left(\mathrm{C}_{\mathrm{t} \text {, target gene }}-\mathrm{C}_{\mathrm{t}, \beta \text {-actin }}\right)_{\mathrm{PCBs}}-\left(\mathrm{C}_{\mathrm{t} \text {, target gene }}-\mathrm{C}_{\mathrm{t}, \beta \text {-actin }}\right)_{\text {control }}$ (Livak and Schmittgen 2001).

\section{Statistical analysis}

All the experimental data are reported as means \pm standard deviation of the mean (SD). Data were tested for normality (Shapiro-Wilk test) and homogeneity of variance (Levene test) prior to analyses. The data were analyzed with one-way analysis of variance (ANOVA) followed by the least significant difference (LSD) test (Ahmad et al., 2006) using SPSS Statistics 18.0 (SPSS Inc., Chicago, IL, USA), with $\mathrm{P}<0.05$ indicating a significant difference. Data that did not conform to assumptions of normality and homoscedasticity were transformed $(\mathrm{lg})$ and then analyzed as described above.

\section{RESULTS AND DISCUSSION}

GSH prevents free radical damage and helps detoxification by conjugating with chemicals and it acts as an essential cofactor for antioxidant enzymes, including glutathione peroxidase and glutathione reductase. T-GSH and MDA were significantly decreased in PCBexposure groups at 7 days (Table 1). Induction in the levels of MDA in the present study was in agreement with the study performed by Mozhdeganloo et al. (2015), which indicated that increased MDA content occurred in rainbow trout (Oncorhynchus mykiss) exposed to methylmercury. All of the antioxidative parameters significantly decreased and increased at 14 and 21 days, respectively, except for T-GSH for the $5 \mathrm{mg} / \mathrm{L}$ PCB-exposure groups at 21 days (Table 1). Decreased T-GSH observed at 7 and 14 days was similar to methylmercury-exposed rainbow trout (Mozhdeganloo et al., 2015), whereas the increased T-GSH observed at 21 days $(0.5 \mathrm{mg} / \mathrm{L})$ was the same as that following waterborne lead exposure in tilapia (Kaya and Akbulut, 2015). The increased GSH levels in the liver were explained by the enhanced hepatic uptake of amino acid substrates and activity of biosynthetic enzymes leading to the protection of the fish from oxidative damage. GSH/GSSG was significantly decreased (2.13-fold) and increased (1.25-fold) for 0.5 and $5 \mathrm{mg} / \mathrm{L}$ PCB-exposure groups, respectively, at 7 days (Table 1). Increased detoxification of ROS implies the oxidation of GSH to GSSG (Guzmán-Guillén et al., 2013), which was similar to results observed for tilapia livers following spinosad exposure (Piner and Üner, 2013). The alteration of GSH content and metabolism in different studies suggest that GSH has a key role in oxidative-induced toxicity caused by PCBs.

Genetics and Molecular Research 15 (3): gmr.15038613 
Oxidation stress in GIFT exposed to PCBs

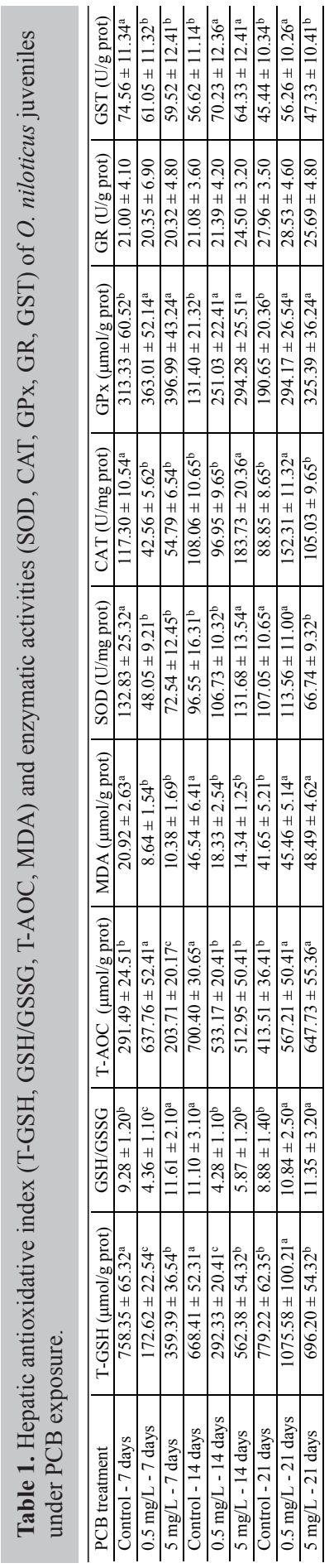

Genetics and Molecular Research 15 (3): gmr.15038613 
SOD and CAT comprise the first-line defense against oxygen toxicity and serve as early indicators of exposure to pollutants that trigger oxidative stress. The activities of SOD, CAT, and GST have been shown to respond differently to chlorpyrifos exposure (Jin et al., 2015). In the present study, SOD, CAT, and GST showed significant decreases following PCB exposure at 7 days (Table 1), only SOD (1.36-fold) and CAT (1.70-fold) showed significant increases for $5 \mathrm{mg} / \mathrm{L}$ PCBs (14 days), whereas GST (1.24-fold) and CAT (1.71-fold) showed significant increases for $0.5 \mathrm{mg} / \mathrm{L} \mathrm{PCB}$ exposure at 21 days (Table 1). CAT and GPx can act cooperatively as scavengers of $\mathrm{H}_{2} \mathrm{O}_{2}$ and other hydroperoxides. Vieira et al. (2012) reported that the decreased CAT activity was concomitant with stimulated SOD and GPx activity in goldfish under acute toxicity following manganese exposure. GPx showed significant changes in the current study (1.16- and 1.17-fold for 0.5 and $5 \mathrm{mg} / \mathrm{L}$ PCB-exposure groups, respectively). GPx showed significant changes following PCB exposure at both 14 and 21 days, whereas SOD activity decreased (1.60-fold) for the $5 \mathrm{mg} / \mathrm{L}$ PCB-exposure groups at 21 days (Table 1). The present study showed the reverse tendency between SOD, CAT, and GPx activity for treated groups at 7 days, where CAT activity was increased in treated groups at 14 and 21 days in the present study, which demonstrated that CAT activity could be compensated for by a large decrease in GPx activity (Atli and Canli, 2011).

GST is an important phase II detoxification enzyme, playing important roles in protecting tissues against the oxidative damage of diverse electrophilic endogenous and xenobiotic substrates by way of conjugation with glutathione to produce less toxic and more water-soluble compounds. Increased GST activity has been previously observed in Leuciscus cephalus exposed to heavy metals, which was related to milder structural changes observed in the liver compared to the kidney (Hermenean et al., 2015). GST activity was also significantly induced in the liver of fish exposed to PCBs in this study, and the liver showed congestion only for $5 \mathrm{mg} / \mathrm{L}$ PCB-exposure groups at 21 days in the present study (Figure 1). The bioaccumulation of PCBs in juvenile $O$. niloticus livers was significantly up-regulated 2.35-, 3.07-fold at 7 days, and 1.77-, 2.31-fold at 14 days under 0.5 and $5 \mathrm{mg} / \mathrm{L} \mathrm{PCB}$ exposure, respectively. It was only significantly up-regulated (2.34-fold) in the $5 \mathrm{mg} / \mathrm{L} \mathrm{PCB}$-exposure groups at 21 days (Figure 2). T-AOC was significantly increased (2.19-fold) and significantly declined (1.43-fold) for 0.5 and $5 \mathrm{mg} / \mathrm{L}$ PCB-exposure groups, respectively, at 7 days (Table 1). However, GR activity was not affected throughout the exposure period. The frequently used markers (SOD and CAT), GSH-related antioxidant system (GPx, GST, and GSH), T-AOC, and MDA are reliable environmental biomarkers for PCB-induced oxidative stress in juvenile tilapia. Therefore, they are useful biological indicators of environmental contamination that could be used in aquatic ecosystems (Kayode et al., 2014).

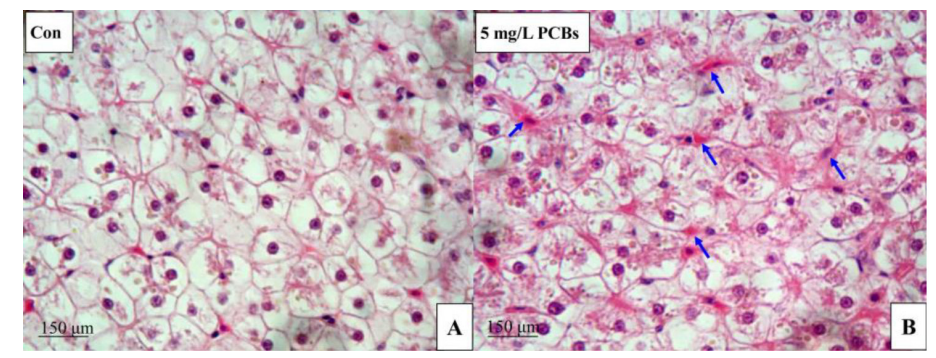

Figure 1. Histological slices for liver of Oreochromis niloticus juveniles under PCB exposure. Blue arrows show liver congestion.

Genetics and Molecular Research 15 (3): gmr.15038613 


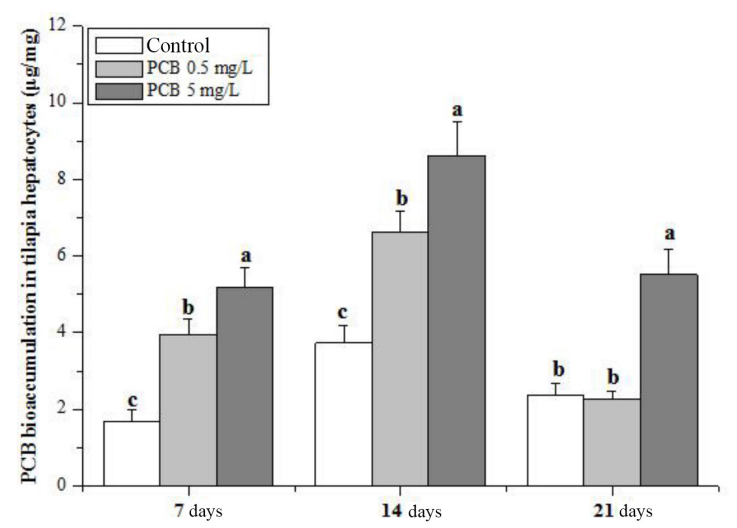

Figure 2. Polychlorinated biphenyl (PCB) bioaccumulation in liver of Oreochromis niloticus juveniles under PCB exposure. The different lower letters indicate statistically highly significant differences $(\mathrm{P}<0.05)$.

Gene expression levels of sod, cat, gr, and gpxl in the spleen and head kidney of juvenile Jian carp (Cyprinus carpio var. jian) after challenges were down-regulated by dietary choline (Wu et al., 2014b). The transcriptional and functional responses of hepatic antioxidant enzymes were inversely correlated in common carp (Cyprinus carpio) exposed to organochlorine pesticides (Karaca et al., 2014), which was demonstrated in tilapia exposed to PCBs. In the current study, sod, cat, and gst showed significant decreases following PCB exposure at 7 days, whereas gpxl showed significant increases (Table 2). Except for cat (0.5 $\mathrm{mg} / \mathrm{L} \mathrm{PCBs})$, sod, and gst transcripts ( $5 \mathrm{mg} / \mathrm{L} \mathrm{PCBs})$, the detected genes were significantly induced at 14 days (Table 2). All of the antioxidative enzymatic genes detected in the present study showed significant increases following PCBs exposure at 21 days, except for $g r$ and $s o d$ transcripts $(0.5 \mathrm{mg} / \mathrm{L}$ PCBs; Table 2$)$.

Table 2. Transcriptional hepatic gene expression profiles of Oreochromis niloticus juveniles under polychlorinated biphenyl (PCB) exposure.

\begin{tabular}{|c|c|c|c|c|c|c|}
\hline & Treatment & sod & cat & $g p x 1$ & $g r$ & gst \\
\hline \multirow[t]{3}{*}{ Day 7} & Control & $1.09 \pm 0.14^{\mathrm{a}}$ & $1.01 \pm 0.13^{\mathrm{a}}$ & $1.08 \pm 0.17^{\mathrm{b}}$ & $1.00 \pm 0.24$ & $1.04 \pm 0.07^{\mathrm{a}}$ \\
\hline & PCB $0.5 \mathrm{mg} / \mathrm{L}$ & $0.38 \pm 0.13^{\mathrm{b}}$ & $0.77 \pm 0.11^{\mathrm{b}}$ & $2.58 \pm 0.25^{\mathrm{a}}$ & $1.17 \pm 0.07$ & $0.73 \pm 0.13^{\mathrm{b}}$ \\
\hline & PCB $5 \mathrm{mg} / \mathrm{L}$ & $0.31 \pm 0.09^{\mathrm{b}}$ & $0.46 \pm 0.12^{\mathrm{b}}$ & $2.24 \pm 0.31^{\mathrm{a}}$ & $1.26 \pm 0.13$ & $0.59 \pm 0.12^{\mathrm{b}}$ \\
\hline \multirow[t]{3}{*}{ Day 14} & Control & $1.05 \pm 0.24^{\mathrm{b}}$ & $1.01 \pm 0.07^{\mathrm{b}}$ & $1.07 \pm 0.09^{\mathrm{b}}$ & $1.00 \pm 0.14$ & $1.06 \pm 0.07^{\mathrm{b}}$ \\
\hline & PCB $0.5 \mathrm{mg} / \mathrm{L}$ & $2.32 \pm 0.22^{\mathrm{a}}$ & $1.28 \pm 0.09^{\mathrm{b}}$ & $5.23 \pm 0.07^{\mathrm{a}}$ & $1.24 \pm 0.38$ & $2.85 \pm 0.13^{\mathrm{a}}$ \\
\hline & PCB $5 \mathrm{mg} / \mathrm{L}$ & $1.48 \pm 0.29^{\mathrm{b}}$ & $2.95 \pm 0.24^{\mathrm{a}}$ & $4.57 \pm 0.24^{\mathrm{a}}$ & $1.28 \pm 0.12$ & $1.21 \pm 0.17^{\mathrm{b}}$ \\
\hline \multirow[t]{3}{*}{ Day 21} & Control & $1.02 \pm 0.18^{\mathrm{b}}$ & $1.04 \pm 0.08^{\mathrm{b}}$ & $1.02 \pm 0.13^{\mathrm{b}}$ & $1.00 \pm 0.11$ & $1.09 \pm 0.12^{\mathrm{c}}$ \\
\hline & PCB $0.5 \mathrm{mg} / \mathrm{L}$ & $1.26 \pm 0.13^{\mathrm{b}}$ & $3.05 \pm 0.12^{\mathrm{a}}$ & $2.39 \pm 0.11^{\mathrm{a}}$ & $1.29 \pm 0.04$ & $3.19 \pm 0.09^{\mathrm{a}}$ \\
\hline & PCB $5 \mathrm{mg} / \mathrm{L}$ & $3.48 \pm 0.09^{\mathrm{a}}$ & $3.59 \pm 0.09^{\mathrm{a}}$ & $2.90 \pm 0.26^{\mathrm{a}}$ & $1.35 \pm 0.16$ & $2.29 \pm 0.10^{\mathrm{b}}$ \\
\hline
\end{tabular}

Different superscript letters indicate statistically significant differences.

This study indicated that transcripts of the detected antioxidative enzymes were significantly decreased at first ( 7 days) and then increased (14 and 21 days), and the transcriptional changes in these genes in the liver could be good biomarkers for stress levels (Woo et al., 2009). Cu exposure up-regulated sod, cat, and $g r$ mRNA levels, which suggested an adaptive mechanism against stress in Jian carp (Jiang et al., 2014). This study suggested that although PCBs stimulate adaptive increases in the expression of some antioxidant enzyme genes, they also induce oxidation and the depletion of most of the antioxidant enzyme activities 
and GSH content because of increases in ROS production (Meng et al., 2014). To conclude, the present study presented hepatic impairment of juvenile GIFT following PCB exposure in the form of significant toxic bioaccumulation, blood congestion, and increased antioxidative enzyme activities and transcripts.

\section{Conflicts of interest}

The authors declare no conflict of interest.

\section{ACKNOWLEDGMENTS}

We thank Kamira Barry and Nikesh Gosalia for providing grammar and spelling check of the manuscript. Research supported by the Special Fund of Fundamental Scientific Research Business Expense for Central Public Research Institutes (Grant \#2015JBFR03) and the China Agriculture Research System (\#CARS-49).

\section{REFERENCES}

Ahmad I, Maria VL, Oliveira M, Pacheco M, et al. (2006). Oxidative stress and genotoxic effects in gill and kidney of Anguilla Anguilla L. exposed to chromium with or without pre-exposure to $\beta$-naphthoflavone. Mut. Res. 608: 16-28. http://dx.doi.org/10.1016/j.mrgentox.2006.04.020

Atli $\mathrm{G}$ and Canli M (2011). Essential metal (Cu, Zn) exposures alter the activity of ATPases in gill, kidney and muscle of tilapia Oreochromis niloticus. Ecotoxicology 20: 1861-1869.http://dx.doi.org/10.1007/s10646-011-0724-z

Gabriel NN, Qiang J, Ma XY, He J, et al. (2015). Dietary Aloe vera improves plasma lipid profile, antioxidant, and hepatoprotective enzyme activities in GIFT-tilapia (Oreochromis niloticus) after Streptococcus iniae challenge. Fish Physiol. Biochem. 41: 1321-1332.http://dx.doi.org/10.1007/s10695-015-0088-z

Ge J, Yun X, Liu M, Yang Y, et al. (2014). Distribution, potential source and ecotoxicological risk of polychlorinated biphenyls and polybrominated diphenyl ethers in the surface water of the Three Gorges Dam region of the Yangtze River, China. Ecotoxicology 23: 978-987.http://dx.doi.org/10.1007/s10646-014-1241-7

Guzmán-Guillén R, Prieto AI, Vasconcelos VM and Cameán AM (2013). Cyanobacterium producing cylindrospermopsin cause oxidative stress at environmentally relevant concentrations in sub-chronically exposed tilapia (Oreochromis niloticus). Chemosphere 90: 1184-1194. http://dx.doi.org/10.1016/j.chemosphere.2012.09.027

Hermenean A, Damache G, Albu P, Ardelean A, et al. (2015). Histopatological alterations and oxidative stress in liver and kidney of Leuciscus cephalus following exposure to heavy metals in the Tur River, North Western Romania. Ecotoxicol. Environ. Saf. 119: 198-205.http://dx.doi.org/10.1016/j.ecoenv.2015.05.029

Jiang WD, Liu Y, Hu K, Jiang J, et al. (2014). Copper exposure induces oxidative injury, disturbs the antioxidant system and changes the Nrf2/ARE (CuZnSOD) signaling in the fish brain: protective effects of myo-inositol. Aquat. Toxicol. 155: 301-313. http://dx.doi.org/10.1016/j.aquatox.2014.07.003

Jin Y, Liu Z, Peng T and Fu Z (2015). The toxicity of chlorpyrifos on the early life stage of zebrafish: a survey on the endpoints at development, locomotor behavior, oxidative stress and immunotoxicity. Fish Shellfish Immunol. 43: 405-414.http://dx.doi.org/10.1016/j.fsi.2015.01.010

Karaca M, Varışlı L, Korkmaz K, Özaydın O, et al. (2014). Organochlorine pesticides and antioxidant enzymes are inversely correlated with liver enzyme gene expression in Cyprinus carpio. Toxicol. Lett. 230: 198-207. http://dx.doi. org/10.1016/j.toxlet.2014.02.013

Kaya H and Akbulut M (2015). Effects of Waterborne Lead Exposure in Mozambique Tilapia: Oxidative Stress, Osmoregulatory Responses, and Tissue Accumulation. J. Aquat. Anim. Health 27: 77-87. http://dx.doi.org/10.1080/ $\underline{08997659.2014 .1001533}$

Kayode SJ, Chidimma UI and Alwell EE (2014). Response of some antioxidant parameters in post juveniles of Clarias gariepinus after exposure to nigerian crude oil (Forcados, Bonny Light and Qua-Iboe). Pak. J. Biol. Sci. 17: 12251230. http://dx.doi.org/10.3923/pjbs.2014.1225.1230

Kim YJ, Yokozawa T and Chung HY (2005). Suppression of oxidative stress in aging NZB/NZW mice: effect of fish oil feeding on hepatic antioxidant status and guanidino compounds. Free Radical Res. 39: 1101-1110. http://dx.doi. $\underline{\text { org } / 10.1080 / 10715760500250083}$

Genetics and Molecular Research 15 (3): gmr.15038613 
Li M, Zheng Y, Liang H, Zou L, et al. (2013). Molecular cloning and characterization of cat, gpx1 and Cu/Zn-sod in pengze crucian carp (Carassius auratus var. Pengze) and antioxidant enzymes modulation induced by hexavalent chromium in juveniles. Comp. Biochem. Physiol. C. 157: 310-321.

Livak KJ and Schmittgen TD (2001). Analysis of relative gene expression data using realtime quantitative PCR and the $2^{-\Delta \Delta \mathrm{Ct}}$ method. Methods 25: 402-408. http://dx.doi.org/10.1006/meth.2001.1262

Meng SL, Chen JZ, Hu GD, Song C, et al. (2014). Effects of chronic exposure of methomyl on the antioxidant system in liver of Nile tilapia (Oreochromis niloticus). Ecotoxicol. Environ. Saf. 101: 1-6. http://dx.doi.org/10.1016/j. ecoenv.2013.10.020

Mozhdeganloo Z, Jafari AM, Koohi MK and Heidarpour M (2015). Methylmercury-induced oxidative stress in rainbow trout (Oncorhynchus mykiss) liver: ameliorating effect of vitamin C. Biol. Trace Elem. Res. 165: 103-109. http:// dx.doi.org/10.1007/s12011-015-0241-7

Ottonello G, Ferrari A and Magi E (2014). Determination of polychlorinated biphenyls in fish: optimisation and validation of a method based on accelerated solvent extraction and gas chromatography-mass spectrometry. Food Chem. 142: 327-333. http://dx.doi.org/10.1016/j.foodchem.2013.07.048

Piner P and Üner N (2013). Oxidative stress and apoptosis was induced by bio-insecticide spinosad in the liver of Oreochromis niloticus. Environ. Toxicol. Pharmacol. 36: 956-963. http://dx.doi.org/10.1016/j.etap.2013.08.009

Storelli MM, Barone G, Perrone VG and Giacominelli-Stuffler R (2011). Polychlorinated biphenyls (PCBs), dioxins and furans (PCDD/Fs): Occurrence in fishery products and dietary intake. Food Chem. 127: 1648-1652. http://dx.doi. org/10.1016/j.foodchem.2011.02.032

Vieira MC, Torronteras R, Córdoba F and Canalejo A (2012). Acute toxicity of manganese in goldfish Carassius auratus is associated with oxidative stress and organ specific antioxidant responses. Ecotoxicol. Environ. Saf. 78: 212-217. http://dx.doi.org/10.1016/j.ecoenv.2011.11.015

Woo S, Yum S, Kim DW and Park HS (2009). Transcripts level responses in a marine medaka (Oryzias javanicus) exposed to organophosphorus pesticide. Comp. Biochem. Physiol. C. 149: 427-432.

Wu F, Zheng Y, Gao J, Chen S, et al. (2014a). Induction of oxidative stress and the transcription of genes related to apoptosis in rare minnow (Gobiocypris rarus) larvae with Aroclor 1254 exposure. Ecotoxicol. Environ. Saf. 110: 254-260. http://dx.doi.org/10.1016/j.ecoenv.2014.09.012

Wu P, Jiang WD, Liu Y, Chen GF, et al. (2014b). Effect of choline on antioxidant defenses and gene expressions of Nrf2 signaling molecule in the spleen and head kidney of juvenile Jian carp (Cyprinus carpio var. Jian). Fish Shellfish Immunol. 38: 374-382.http://dx.doi.org/10.1016/j.fsi.2014.03.032

Zhang Q, Zhu J, Ye J, Qian Y, et al. (2016). Temporal trends and risk assessment of polychlorinated biphenyls and heavy metals in a solid waste site in Taizhou, China. Environ. Sci. Pollut. Res. Int. 23: 438-446.

Zheng Y, Wang L, Li M, Liang H, et al. (2013). Molecular characterization of five steroid receptors from pengze crucian carp and their expression profiles of juveniles in response to $17 \alpha$-ethinylestradiol and $17 \alpha$-methyltestosterone. Gen. Comp. Endocrinol. 191: 113-122. http://dx.doi.org/10.1016/j.ygcen.2013.06.011

Zheng Y, Liang H, Xu P, Li M, et al. (2014). Molecular cloning of Pcc-dmrt1s and their specific expression patterns in Pengze crucian carp (Carassius auratus var. Pengze) affected by $17 \alpha$-methyltestosterone. Fish Physiol. Biochem. 40: 1141-1155.

\section{Supplementary material}

Table S1. Primers of tilapia used for qRT-PCR in the study.

Genetics and Molecular Research 15 (3): gmr.15038613 